\title{
A FEDEZETT KÖTVÉNYEK MINŐSÍTÉSÉNEK GYAKORLATA
}

Mérő Katalin ${ }^{1}$

\begin{abstract}
ABSZTRAKT
A cikk azt elemzi és hasonlítja össze, hogy az európai fedezett kötvények (covered bond) minősítésénében 99\%-os piaci lefedettséget adó öt hitelminősítő - a Moody's, az S\&P, a Fitch, a DBRS és a Scope - gyakorlatában hogyan történik a fedezett kötvények minősítése. Ezek minősítése általában kiváló, és akár számottevően is meghaladhatja úgy a kibocsátó bank, mint a bank székhelyéül szolgáló ország minősítését. Ennek fő okát a különféle, szabályozásban rögzített védelmi vonalak jelentik, amelyeket piaci oldalról az Európai Központi Bank nagy volumenű fedezettkötvény-vásárlási programja is támogat. Kérdés azonban, hogy egy jelentős ingatlanpiaci turbulencia vagy rendszerszintü bankválság, esetleg egy szuverén válság körülményei között ezek a védelmi vonalak valóban teljes hatékonysággal bevethetőek-e, vagyis a fedezett kötvények minősítésének jelenlegi gyakorlata nem tekinthető-e túlzottan optimistának.
\end{abstract}

JEL-kódok: G21, G23, G28

Kulcsszavak: fedezett kötvények, hitelminősítők

\section{BEVEZETÉS}

Az amerikai subprime válság és az abból kiinduló 2008-as globális pénzügyi válság egyik felelőseként a szakirodalom gyakran nevezi meg a hitelminősítő ügynökségeket (White, 2009, Mullard, 2012, Scalet-Kelly, 2012). A válság előtti években egyre növekvő volumenben kibocsátott, magas kockázatú lakossági jelzáloghitel-portfóliókból képzett, nehezen áttekinthető kockázatokat hordozó strukturált kötvényeknek (az úgynevezett CDO-knak²) a hitelminősítők kimagaslóan jó minősítést adtak, ami a befektetők számára azt az információt közvetítette, hogy ezek a kötvények minimális kockázatot hordoznak. Amikor az amerikai ingatlanpiaci árak csökkenni kezdtek, ezek a kiváló minősítésü kötvények - a mögöttes hitelportfóliók minőségének romlása következtében - sorra igen kocká-

1 Mérő Katalin egyetemi docens, Budapesti Gazdasági Egyetem. E-mail: Mero.Katalin@uni-bge.hu. 
zatossá, gyakran nemteljesítővé váltak. A hitelminősítők pedig csak akkor léptek, amikor ez a folyamat már bekövetkezett, vagyis egyik pillanatról a másikra több kategóriával rontották a CDO-k minősítését. A korábban AAA vagy AA minősítésü CDO-kat hirtelen tömegesen a spekulatív kategóriák valamelyikébe sorolták át. Ezzel a magatartással a hitelminősítők egyrészt valóban a válság egyik felelősévé váltak, másrészt aláásták a befektetőknek a minősítésekbe vetett bizalmát.

A válságot követően a korábban teljesen szabályozatlanul, kizárólag piaci alapon működő hitelminősítők szabályozott és felügyelt intézményekké váltak. Az Európai Unióban a hitelminősítők tevékenységét egy rendelet és egy irányelv szabályozza $^{3}$, felügyeletüket pedig az Európai Értékpapír-piaci Hatóság (ESMA) látja el. A szabályozás céljai között szerepel a minősítések minőségének javítása, a hitelminősítők módszertanának átláthatóvá tétele és a kiadott minősítéseikkel kapcsolatos elszámoltathatóságuk növelése. Mindezek alapján azt gondolhatnánk, hogy mára a hitelminősítés valóban a befektetések kockázatosságának megfelelő megítélését szolgáló, igen megbízható eszköznek tekinthető, még a laikusok számára viszonylag bonyolultabban átlátható kockázatosságú kötvénykibocsátások vonatkozásában is.

Ebben a cikkben azt elemezzük, hogy egy speciális termékcsoport - a strukturált finanszírozási termékek közé tartozó fedezett kötvények (covered bond) - tekintetében mennyiben igaz az, hogy ezeknek a kötvényeknek a minősítése a mögöttes termékek kockázatait jól tükrözi, és így a befektetőket megfelelően orientálja. A fedezett kötvények olyan kötvények, amelyeket bankok bocsátanak ki úgy, hogy egy adott hitelportfóliót kötvény formájába csomagolnak össze, és ezt a kötvényt eladják. Az eredeti hitelek benne maradnak a bank könyveiben. A kötvények fedezetét jelentő hiteleket a bankok a többi eszköztől elkülönítve tartják nyilván, mert ezek a hitelek és a mögöttük lévő fedezetek speciális biztosítékként szolgálnak a kötvénytulajdonosok számára. Fedezett kötvényeket jellemzően lakossági jelzáloghitelek és a közszférának nyújtott hitelek értékpapírosítására bocsájtanak ki. A fedezett kötvények alapvetően különböznek a globális pénzügyi válságot megelőzően elterjedt CDO-któl. A hasonlóság csak abban áll, hogy mindkét kötvénytípus mögött jelzáloghitelek jelentik a fedezetet. Azonban a fedezett kötvények a CDO-knál jóval egyszerűbb és átláthatóbb kockázatú termékek, hiszen azoknál a hitelek és a mögöttes fedezetek nem szakadnak el egymástól. Emellett számos, a következő részben bemutatott strukturális sajátosság (kettős fedezettség, túlfedezettség) és szabályozási védelem is hozzájárul ahhoz, hogy a fedezett kötvények az alacsony kockázatú pénzügyi eszközök közé tartozzanak, szemben az igen kockázatos CDO-kkal vagy akár a fedezetlen banki kötvényekkel is.

3 Regulation No 462/2013 és Directive 2013/14/EU. 
Elemzésünkben csak az Európai Unióban kibocsátott fedezett kötvényekre fókuszálunk, mivel ezekre vonatkozik az EU (többé-kevésbé) egységes szabályozási rendszere, így ezek a kötvények viszonylag homogén termékcsoportként kezelhetők. Az elemzés során nem állítunk fel saját kockázatértékelő modellt, amelyet a hitelminősítők modelljeivel összevethetnénk, hanem a hitelminősítők által alkalmazott minősítés folyamatát, módszertani lépéseit követjük végig, hasonlítjuk össze és értékeljük a három piacvezető hitelminősítő (Moody’s, Standard and Poor és Fitch), valamint a strukturált termékek minősítése tekintetében Európában az őket követő két legnagyobb, de már a kicsik közé sorolható hitelminősítő (DBRS Ratings és Scope Ratings) tevékenysége alapján.

A fedezett kötvények minősítésének gyakorlata azért különösen érdekes, mert 2008 előtt gyakorlatilag kizárólag a legjobb minősítési kategóriába tartozó AAA minősítésű fedezett kötvények voltak a piacon. 2008-at követően már találkozunk ettől elmaradó minősítésű fedezett kötvényekkel is, de jellemzően a mai napig kiváló (legalább A-s) minősítésü kötvények tartoznak ebbe a kategóriába.

A cikk felépítése a következő. A bevezetést követően először nagyon röviden bemutatjuk az európai fedezettkötvény-piacot, majd azokat a szabályozási elemeket foglaljuk össze, amelyek a fedezett kötvények kockázatossága és a rájuk vonatkozó minősítések szempontjából meghatározóak. Ezt követően hasonlítjuk össze és elemezzük az öt hitelminősítő fedezettkötvény-minősítési gyakorlatát. A cikk néhány következtetés levonásával zárul.

\section{FEDEZETT KÖTVÉNYEK PIACA AZ EU-BAN}

A fedezett kötvények piaca jellemzően európai piac, csak az elmúlt néhány évben indult fejlődésnek több Európán kívüli országban is. Számos európai országban a lakossági jelzáloghitelek refinanszírozásának tradicionális és általánosan elterjedt formája, hogy a hitelt nyújtó bankok jelzálogkötvényeket bocsátanak ki. A megfinanszírozott ingatlanok a kötvények fedezetéül szolgálnak, így a jelzálogkötvények a tőkepiacokon a biztonságos (és egyben alacsony kamatozású) kötvények közé tartoznak. A jelzálogkötvényekkel megegyező kötvénykibocsátási konstrukcióval refinanszírozhatják a bankok a közszférának nyújtott hiteleket is, illetve egy-két ország gyakorlatában még a hajók finanszírozása is történhet ebben a formában (ECBC, 2020). Ezek együttesét nevezzük fedezett kötvényeknek. A fedezett kötvények legfőbb jellegzetessége az ún. kettős fedezettség (dual recourse), vagyis az, hogy a kötvényekhez kapcsolódó kifizetésekért elsősorban a kötvényt kibocsátó bank áll helyt, de a bank esetleges csődje esetén a mögöttes fedezetekből elsőként kell a kötvénytulajdonosokat kifizetni; amíg ez nem történt meg, addig a fedezetek más célra nem használhatóak fel. További sajátossága a 
fedezett kötvényeknek, hogy a kötvények mögötti fedezetek értéke nagyobb, mit a kötvények kibocsátáskori értéke. Erre a túlfedezettségre azért van szükség, hogy az ingatlanárak esetleges csökkenése esetén is megfelelő maradjon a kötvények mögötti fedezetek értéke. A fedezettkötvény-finanszírozásra a következő részben bemutatott, elkülönült szabályozási rendszer vonatkozik.

A fedezett kötvények az európai kötvénypiacokon meghatározó jelentőségűek. 2015-ben a fedezett kötvények 2,1 milliárd eurós állománya 17 százalékkal meghaladta az összes nem pénzügyi vállalkozások által kibocsátott kötvények 1,8 milliárd eurós állományát (Kemmish et al., 2017). Az európai fedezettkötvénypiac erősen koncentrált, a négy legnagyobb kibocsátó ország a teljes európai fedezettkötvény-állomány 64\%-át teszi ki (1. táblázat). Az országonként mutatkozó különbségek hátterében az áll, hogy az egyes országokban a lakossági jelzáloghitelezésen belül különbözik a fedezett kötvényekkel való finanszírozás súlya. Dániában kizárólag fedezettkötvény-finanszírozással történik a lakossági jelzáloghitelezés, 40-60\% közötti aránya van Svédországban, Finnországban és Olaszországban, közelíti a 40\%-ot Portugáliában és Spanyolországban, 20\% körül van Németországban és 15-20\% közötti értéket képvisel Franciaországban és Hollandiában (Stöcker, 2020). A 2010-es években a közszférának nyújtott hitelek refinanszírozására kibocsátott kötvények állománya folyamatosan csökkent, míg a jelzáloghitelek refinanszírozására kibocsátott kötvényeké számottevően nőtt (2. táblázat).

A fedezett kötvények kibocsátását az is nagyban támogatja, hogy az Európai Központi Bank (EKB) eszközvásárlási programja keretében is jelentős fedezettkötvényvásárlásokat eszközöl. Az EKB első fedezettkötvény-vásárlási programja 2009 júliusában indult, és egy év alatt 60 milliárd eurós fedezettkötvény-vásárlást jelentett, amelyet az EKB lejáratig tervez a portfóliójában tartani. A második fedezettkötvény-vásárlási program 2011 novembere és 2012 októbere között 16,4 milliárd eurós volt, szintén a lejáratig tartás szándékával. Az EKB harmadik fedezettkötvény-vásárlási programja 2014 októberétől 2018 decemberéig tartott, majd 2019 januárja óta a lejárt kötvények visszafizetéséből származó összegeket fekteti be újra fedezett kötvényekbe. A harmadik kötvényvásárlási program keretében az EKB 2019 óta újra vásárol fedezett kötvényeket nemcsak a lejártak helyett, hanem folyamatosan növelve is a portfólióját. 2021 februárjában a harmadik fedezettkötvény-vásárlási program keretében megvásárolt, összes kötvény állománya 289 milliárd euró volt. ${ }^{4}$

4 https://www.ecb.europa.eu/mopo/implement/app/html/index.en.html. 


\section{1. táblázat}

A fedezett kötvények állománya az EU-ban és az EU-n kívül (2019, milliárd euró)

\begin{tabular}{lc}
\hline EU összesen & 2128,8 \\
\hline Ebből a legnagyobbak: & \\
Dánia & 419,4 \\
Németország & 364,1 \\
Franciaország & 334,2 \\
Spanyolország & 241,5 \\
EU-n kívüli országok & 576,7 \\
\hline Összesen & 2705,5 \\
\hline
\end{tabular}

Megjegyzés: Az Egyesült Királyság a táblázatban már az EU-n kívüli országok között szerepel. Forrás: ECBC (2020)

\section{2. táblázat}

A fedezett kötvények globális állománya a mögöttes hitelek típusa szerint (2010-2019, milliárd euró)

\begin{tabular}{lcccccccccc}
\hline & 2010 & 2011 & 2012 & 2013 & 2014 & 2015 & 2016 & 2017 & 2018 & 2019 \\
\hline Közszféra & 653,0 & 616,5 & 544,0 & 464,8 & 408,6 & 371,5 & 335,5 & 312,5 & 294,0 & 282,7 \\
Jelzálog & 1836,4 & 2041,6 & 2245,4 & 2131,2 & 2088,5 & 2116,1 & 2146,5 & 2140,3 & 2275,8 & 2414,0 \\
\hline
\end{tabular}

Forrás: ECBC (2020)

A jövőben a fedezettkötvény-kibocsátás szerepének további erősödése várható, mivel a piaci szegmens fejlesztése az Európai Tőkepiaci Unió megteremtésére vonatkozó, 2015-ös akciótervnek is az egyik fontos pillére (EC, 2015), valamint mert az Európai Központi Bank eszköztárában is folyamatosan meghatározó szerepe van a fedezett kötvények vásárlása melletti likviditásnyújtásnak. 


\section{A FEDEZETT KÖTVÉNYEK ÉS A HITELMINŐSÍTÖK SZABÁLYOZÁSA AZ EU-BAN}

\subsection{A fedezett kötvények szabályozása}

Az EU-ban a fedezett kötvények átfogó és részletes szabályozása a tőkepiaci unió akciótervének keretében, 2019-ben történt a fedezett kötvényekre vonatkozó irányelv elfogadásával. ${ }^{5}$ Ezt a tagállamoknak 2021. júliusig kell implementálniuk, és legkésőbb 2022 júliusától alkalmazniuk. Az új szabályozás részletes, elemző ismertetése megtalálható Stöcker (2021)-ben. Az ebben a cikkben elemzett hitelminősítési gyakorlatokat azonban értelemszerűen még a megelőző szabályozás mentén alakították ki. Összességében azonban elmondható, hogy az új szabályozás a fedezett kötvényeket inkább a még kevésbé kockázatos irányba mozdítja el, vagyis az itt bemutatottakhoz képest szigorúbb minősítési gyakorlatra a jövőbe sem kell számítani.

A fedezett kötvényekre vonatkozó 2019-es szabályozás elfogadásáig az Európai Unióban nem volt jogszabályban lefektetett definíciója a fedezett kötvényeknek. A gyakorlatban a kollektív befektetésekre vonatkozó, ún. UCITS-irányelv adott egy definíciót. ${ }^{6}$ Ennek az volt a célja, hogy meghatározza, melyek azok a fedezett kötvények, amelyeket a UCITS-szabályozásnak megfelelö befektetési alapok az általános szabályozásnál nagyobb mértékben tarthatnak a portfóliójukban. Míg alapesetben egy befektetési alap portfóliójában egy adott kibocsátó értékpapírjai maximum 5\%-os részt képviselhetnek, addig a UCITS-definíciónak megfelelő fedezett kötvények esetében ezt a határt 25\%-ban húzták meg, vagyis a szabályozás azt deklarálta, hogy a definíciónak megfelelő fedezett kötvények kockázata kiemelkedően alacsony. Bár ez egy speciális célú definíció, mégis - más definíció híján - az EU-ban ezt a definíciót használták, és tekintették referenciának. A UCITS-szabályozás szerint az EU-ban a szabályozás által elfogadott fedezett kötvényeknek a következő feltételeknek kell megfelelniük:

- azokat az EU-n belül egy, az EU-ban bejegyzéssel rendelkező bank bocsátja ki;

- a kötvények kibocsátóira speciális állami prudenciális felügyelet és a kötvénytulajdonosokat védő állami felügyelet vonatkozik;

- a fedezett kötvény teljes élettartama alatt a fedezett kötvények mögötti eszközök megfelelö biztosítékként szolgálnak a kötvények tulajdonosai számára; és

5 Directive (EU) 2019/2162.

6 Directive 2009/65/EC Article 52. 
- a kötvénykibocsátó bank csődje esetén a kötvénytulajdonosok követelései elsőbbséget élveznek (kettős fedezettség elve).

Az így definiált fedezett kötvényekhez számos további kedvezményt is rendel az EU szabályozási rendszere. A bankok szempontjából komoly tényező, hogy a tőkekövetelmény számítására vonatkozó szabályozás kedvező kockázati súlyozást társít a fedezett kötvényekhez ${ }^{7}$, valamint hogy a fedezett kötvényeket likvid eszközként lehet figyelembe venni a likviditásfedezeti mutató számítása során. ${ }^{8}$ A befektetők szempontjából pedig az jelent komoly kedvezményt, hogy a bankok szanálási folyamatában a fedezett kötvények nem vonhatók be a válságkezelési folyamatba (nem részei hitelezői feltőkésítésnek, az ún. „bail-in”-nek) ${ }^{9}$. A UCITSdefiníciónak megfelelő fedezett kötvényeket fogadja be repóügyletek fedezeteként az Európai Központi Bank is, illetve veheti meg az eszközvásárlási program keretében, ha azok minősítése BBB vagy annál jobb.

Az Európai Bankhatóság, az EBA 2016-ban felmérte a fedezett kötvények EUtagállami szabályozási gyakorlatát (EBA, 2016), és azt összevetette az általa korábban javasolt, a legjobb szabályozási gyakorlatok kialakítására vonatkozó nyolc alapelvvel (EBA, 2014), és arra a megállapításra jutott, hogy a fedezett kötvények tagállami szabályozása nagyon eltérő. A felmérésben 21 olyan EU-tagállam vett részt, amelyeknek van a fedezett kötvényekre vonatkozó nemzeti szabályozása. Egyedül a kettős fedezettségre vonatkozó alapelv volt az, amelynek mind a 21 ország szabályozása megfelelt. Vagyis azt minden ország megfelelően előírta, hogy bár a fedezett kötvényben megtestesülő követelés a kibocsátó bankokkal szemben áll fenn, ha a bank fizetésképtelenné válna, a befektető követelése a kötvény mögötti fedezetekkel (cover pool) szemben továbbra is fennáll, vagyis a kötvény mögötti fedezeteket nem lehet más célra elvonni. Ezenkívül még nagyfokú egyezést mutatnak a nemzeti szabályozások a tekintetben is, hogy a fedezeti eszközöket a bankok jogilag is elkülönítik az egyéb eszközeitől, hogy a kibocsátó csődje esetén a kötvénytulajdonosok továbbra is az eredeti feltételek mentén kapják meg a kifizetéseket, valamint hogy a fedezeti eszközökből származó bevételeknek nemcsak magukra a kötvényhez kapcsolódó tőke- és kamatfizetési kötelezettségre kell fedezetet nyújtaniuk, hanem minden egyéb, a fedezett kötvényekhez kapcsolódó potenciális kifizetésre (beleértve a müködési költségeket is). A szabályozási legjobb gyakorlatokra lefektetett, többi alapelvnek a nemzeti szabályozásoknak csak egy (helyenként kisebb) része felelt meg. Ebbe a kategóriába tartoznak például a

7 CRR Article 129.

8 Commission Delegated Regulation (EU) 2015/61, Articles 11, 12 és 13.

9 Directive 2014/59/EU Article 44. 
likviditási, a nyilvánosságra hozatali, a stressztesztelési vagy a felügyeleti szabályozásra vonatkozó alapelvek.

\subsection{A hitelminősítők szabályozása}

Az Európai Unióban a hitelminősítők szabályozása 2008 után azonnal megkezdődött - akkor még csak a strukturált termékek minősítési rendszerének hibáiból tanulva -, majd 2013-ban lényegesen kibővítették a szabályozást, ekkor már a minősítőknek az európai szuverén válságok során megmutatkozó hibáiból levont tanulságokat (Gaillard, 2013) is beépítve a szabályozásba. A hitelminősítők szabályozására egy uniós rendelet és egy irányelv született ${ }^{10}$, engedélyezésükre, nyilvántartásukra és felügyeletükre pedig a 2010-ben felállított Európai Értékpapír-piaci Hatóságot, az ESMA-t jelölték ki. A szabályozás az eredeti szándék szerint csak arra vonatkozott volna, hogy ahhoz, hogy a különböző pénzügyi intézmények prudenciális szempontból figyelembe vehessék a hitelminősítők minősítéseit, azoknak milyen feltételeknek kell megfelelniük. A végleges szabályozás azonban már sokkal ambiciózusabb célok mentén valósult meg, és általában a minősítési tevékenységre vonatkozik, függetlenül annak felhasználási céljától.

A szabályozás részletes elöírásokat tartalmaz a hitelminősítők által alkalmazandó módszertanokról, modellekről és ezek mögöttes megfontolásairól is. ${ }^{11}$ Eszerint a minősítések kialakítása során a minősítőknek minden a minősítés szempontjából lényeges, rendelkezésre álló információt figyelembe kell venniük. A minősítés módszertanának szigorúnak kell lennie, és olyannak, ami épül a korábbi tapasztalatokra, beleértve az alkalmazott modellek utólagos visszamérését is. A minősítések módszertanát folyamatosan karban kell tartani, és legalább évente felülvizsgálni.

A fedezett kötvények minősítésére - az általános rendelkezéseken túl - vonatkozik a strukturált pénzügyi eszközök kettős hitelminősítésének követelménye is, vagyis az, hogy ezeket a nehezen átlátható kockázati jellemzőkkel rendelkező, bonyolult kötvényeket legalább két, egymástól független hitelminősítővel is minősíttetni kell. A szabályozás azt is erősen ösztönzi, hogy ilyen esetben az egyik hitelminősítő olyan legyen, amelynek a piaci részesedése a teljes minősítési piacon 10 százalék alatti. Ez praktikusan azt jelenti, hogy a fedezett kötvények egyik minősítője sokszor nem a három nagy valamelyike. A módszertanok megfelelésének biztosítására a szabályozás számos szervezeti, müködési, személyi feltételt,

\footnotetext{
10 Regulation 462/2013, Directive 2013/14/EU.

11 Ezeket a rendelet 8. cikke tartalmazza.
} 
valamint a minősítések kialakításához felhasznált információk és módszerek bemutatására vonatkozó elöírást és közzétételi követelményt is elöír.

A szabályozásnak megfelelően a hitelminősítők fedezett kötvények minősítésére vonatkozó módszertana nyilvánosan hozzáférhető, így a következőkben azok alapján hasonlítjuk össze a strukturált termékek piacán legnagyobb öt hitelminősítő módszertanát.

\section{A FEDEZETT KÖTVÉNYEK MINÖSÍTÉSE A HITELMINÖSÍTŐK GYAKORLATÁBAN}

\section{1. Általánosan alkalmazott alapelvek}

A fedezett kötvények bankok által kibocsátott kötvények, így a minősítések során a kiindulópont minden hitelminősítőnél magának a fedezett kötvényt kibocsátó banknak a hitelminősítése. Ugyanakkor a fedezett kötvényekre vonatkozó szabályozás miatt ezekre a kötvényekre mindig igaz, hogy kisebb kockázatot hordoznak, mint a kibocsátó bank egyéb, elkülönített fedezettel nem megerősített kötvényei. A fedezett kötvények tulajdonosai sokszor még akár a kibocsátó bank esetleges bukása esetén is hozzájuthatnak a kötvényben megtestesülő követeléseikhez. Vagyis ha a bank mint kibocsátó beszünteti a kötvényekhez kapcsolódó fizetéseket, a kötvények szabályozási konstrukciójába beépített elemek akkor is lehetővé tehetik a kötvényekhez kapcsolódó kifizetések folyamatosságának fenntartását. Ezt mindegyik minősítő a kibocsátó bank hitelminősítésénél jobb minősítéssel honorálja az erre a célra kialakított módszertana segítségével. Mindegyik módszertan úgy épül fel, hogy meghatározza a minősítési skálán felfelé való elmozdulásra okot adó tényezőket, majd számszerüsíti, hogy az adott tényező megléte miatt hány minősítési egységgel (ún. notch-csal) javítja az adott fedezett kötvény minősítését. A javításra okot adó tényezők mentén adott többlet notch-okat összeadják, és ennyivel javítják a kiinduló bank minősítését. A fedezett kötvény minősítése vagy megegyezik az így kialakuló minősítéssel, vagy ha minősítésre vonatkozik valamilyen felső határ, és azt a minősítés elérte, akkor a felső határnak megfelelő minősítést fogja kapni a fedezett kötvény. A felső határ jellemzően a kibocsátó bank székhely szerinti országának szuverén minősítéséhez kapcsolódik, de annál számottevően jobb. A felfelé való eltérítés lehetősége általában elég nagyvonalú (jellemzően 6 notch), ami azt jelenti, hogy az S\&P vagy a Fitch skáláján akár egy A-, a belföldi pénznemben kibocsátott államkötvényekre vonatkozó minősítésű ország bankja által kibocsátott fedezett kötvény is lehet AAA minősítésű. 
A szabályozásból levezetve a hitelminősítők általában a következő okok miatt javítják a fedezett kötvények minősítését a bankok fedezetlen kötvényeinek minősítéséhez képest:

- a kettős fedezettség elve miatt a bank csődjének esetleges bekövetkezésekor a kötvények mögötti fedezet elkülönítése a többi eszköztől, és csak a fedezett kötények tulajdonosainak kielégítésére való felhasználhatósága;

- a bank szanálása esetén a fedezett kötvényeknek a hitelezői feltőkésítés alól való kivonhatósága;

- a fedezetek halmazának (cover pool) a minősége, ami a nemteljesítési és megtérülési valószínűségek modellezése (várhatóveszteség-alapú modellezés) mellett jellemzően a túlfedezettségre (over collateralization) is kiterjed ${ }^{12}$;

- a fedezett kötvényekhez a kibocsátó bank bukása esetén érvényes, azok időben történő kifizetését lehetővé tevő különféle likviditástámogatási rendszerek.

A fenti okok miatt az egyes hitelminősítők fedezettkötvény-minősítése akár 9-13 notch-csal is jobb lehet, mint ugyanannak a banknak a nem fedezett kötvényére vonatkozó minősítése. Például a S\&P vagy a Fitch minősítési skáláját használva ${ }^{13}$, de a hitelminősítők általános gyakorlatát tekintve a legalább BBB- minősítésű kötvényeket sorolják a hitelminősítők a befektetésre ajánlott kategóriába, míg az ennél rosszabb, $\mathrm{BB}+$ vagy az alatti minősítéssel rendelkező kötvényeket a spekulatív vagy bóvli kategóriába. A bóvli kategória tetejét jelentő $\mathrm{BB}+$ és a legjobb, gyakorlatilag kockázatmentesnek minősített AAA kategória között a különbség 10 notch. Vagyis akár egy bóvli kategóriájúnak vagy éppen csak a befektetési kategória alján lévőnek minősített bank által kibocsátott kötvény minősítése is elég könnyen lehet AAA.

Hazai pénznemben kibocsátott fedezett kötvény esetén ehhez még a három nagy minősítő esetében arra is szükség van, hogy a bank székhely szerinti országának minősítése legalább A- legyen. Az 1. táblázatban szereplő négy nagy európai fedezettkötvény-kibocsátó ország közül Spanyolország minősítése a leggyengébb, a 3 nagy minősítőnél rendre a következö ${ }^{14}$ : S\&P „A” outlook: negatív; Fitch „A-” outlook: stabil; Moody’s „Baa” outlook: stabil. A három minősítő közül az S\&Pnél ez 5, a Fitch-nél 6, míg a Moody’s-nál 7 notch-csal marad el az AAA minősí-

\footnotetext{
12 A túlfedezettség azt mutatja, hogy a kötvényportfólió mögötti fedezetek mennyivel haladják meg a kötvények állományát. Meghatározása a kötvények (banki eszközportfólió) arányában történik. A túlfedezettség növeli a kötvény egységére jutó várható megtérülést.

13 Az öt hitelminősítő minősítési skálájának egymásnak való megfeleltetése a mellékletben található. 142021 március 20-i állapot szerint
} 
téstől. Vagyis, ha az egyéb megfontolások engedik, akkor az országkockázathoz kapcsolódó minősítési plafon okán jelenleg kizárólag a Moody’s-nál nem a legmagasabb, Aaa minősítés a spanyol fedezettkötvény minősítésének felső korlátja, hanem az ennél 1 notch-csal rosszabb Aa1.

A kimagasló minősítéseket alátámaszthatja, hogy a fedezett kötvényekkel kapcsolatban igen jók a történeti tapasztalatok. A Moody’s 1997 és 2019 közötti, bő két évtizedre vonatkozó elemzése szerint (Moody’s Investor Service, 2020a) az általuk minősített fedezettkötvény-kibocsátók közül 33 ment csődbe, de a fedezett kötvények tulajdonosainak egyik esetben sem kellett veszteséget elszenvednie, miközben a 33 esetből négynél (két görög és két ciprusi bank esetében) a betétesek is veszteségeket szenvedtek. Ebben a négy esetben a bankok által kibocsátott fedezetlen kötvények tulajdonosainak is (úgy a szenior, mint a junior kötvények esetében) voltak veszteségei. További három bank esetében pedig a betétesek ugyan nem szenvedtek veszteségeket, de a fedezetlen kötvények tulajdonosai közül a szenior kötvénytulajdonosok már igen. A junior kötvénytulajdonosok pedig csak négy esetben kerülhették el a veszteségeket. Vagyis visszatekintve megállapítható, hogy a fedezett kötvények tényleg kevésbé voltak kockázatosak, mint az ugyanazon bankok által kibocsátott, fedezetlen kötvények. Ezeknek a pozitív múltbeli tapasztalatoknak azonban nincs szilárd elörejelző ereje a jövőre vonatkozóan.

\subsection{Az egyes hitelminősítők módszertana}

A strukturált termékek minősítésének piacán az öt, egyenként több mint 1\%-os részesedéssel rendelkező hitelminősítő piaci részesedését az 1. ábra szemlélteti. A következőkben ezek minősítési gyakorlatát piaci részesedésük csökkenő sorrendjében mutatja be. 


\section{1. ábra}

\section{A hitelminősítők részesedése a strukturált termékek minősítéséből (2020, \%)}

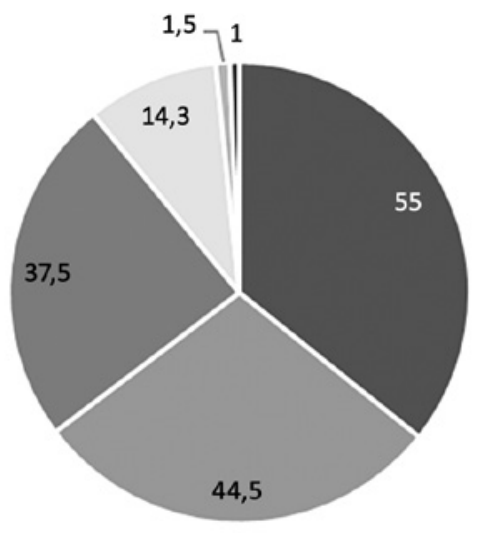

Moody's — Fitch $\square$ S\&P DBRS $\square$ Scope $\square$ többi

Megjegyzés: A százalékok összege azért lehet 100 feletti, mert több olyan strukturált termék is van, amelyet egynél több hitelminősítő is minősít.

Forrás: ESMA (2020).

\subsubsection{Moody's ${ }^{15}$}

A Moody's fedezettkötvény-minősítési modelljének kiindulópontja egy kétlépcsős, várhatóveszteség-alapú modell (expected loss, EL-modell). Ennek keretében az első lépésben történik annak a meghatározása, mekkora annak a valószínűsége, hogy a kibocsátó beszünteti a fedezett kötvényekhez kapcsolódó kifizetéseket, a második lépésben pedig az első eset bekövetkezésekor felmerülő veszteség nagyságát becsülik meg. Ezt követően kerül sor a minősítés finomítására az ún. TPI-indikátor segítségével.

Kiindulópontként a várhatóveszteség-alapú modell keretében a fedezett kötvények kifizetésének beszüntetési valószínűségét a kibocsátó minősítésére alapozva, annál 1 notch-csal jobb minősítésű eseményként határozza meg a Moody's. Ennek oka, hogy itt veszi figyelembe, hogy az európai bankszanálási szabályok értelmében a fedezett kötvények nem vonhatók be egy esetleges hitelezői feltőkésítésbe. Amennyiben a kifizetéseket felfüggesztik, a veszteséget a fedezetek értéke határozza meg. Az EL-modellek a fedezetek értékelésénél három tényezőt vesznek figyelembe: a fedezetek minőségét (beleértve a túlfedezettségből adódó várhatóveszteség-csökkenést is), azt, hogy milyen kockázata van a fedezetek refinanszíro-

15 Az ismertetés alapja: Moody's Investor Service (2O2Ob; 2O2Oc). 
zásának, illetve mekkora kamatkockázat és devizaárfolyamkockázat származik a fedezeti eszközök és az azokat finanszírozó kötvények közötti kamatozási és denominációs eltérésekből. Az EL-modellek eredményének függvényében a minősítés további 2-5 notch-csal javítható.

A TPI-indikátor (timely payment indicator) modellezése keretében annak a valószínüségét határozza meg a Moody's, hogy ha a kibocsátó bank csődbe megy, a kötvénytulajdonosok felé akkor is változatlanul, az eredeti időzítés szerint folytathatók a kifizetések. A TPI szerinti 6 kategória a következő: „nagyon valószínűtlen”, „valószínűtlen”, „lehetséges”, „erősen lehetséges”, „magas”, „nagyon magas”. A TPI legfontosabb összetevője a refinanszírozási kockázat, vagyis annak a kockázata, hogy a fedezett kötvények mögötti eszközök piaci problémák miatt elvesztik a likviditásukat. Emellett a jogi környezetet, az esetlegesen várható állami vagy magánszektorból származó, külső segítségnyújtást, a meglevő fedezeti megállapodásokat, a mögöttes fedezetek típusát (pl. állami garanciával való fedezettség) és az esetlegesen még felmerülő, egyéb tényezőket vizsgálja a Moody’s. A TPI az EL-modell eredményeként kapott minősítéseket további maximum 4 notch-csal javíthatja.

A TPI-indikátorral módosított minősítés összeségében maximum 10 notch-csal lehet jobb a kibocsátó bank minősítésénél. A Moody’s által adható legjobb, Aaa minősítést így „nagyon magas” TPI-besorolásnál akár egy Baaz, vagyis az éppen hogy befektetési kategóriába tartozó minősítésű bank által kibocsátott fedezett kötvény is megkaphatja.

Ezeket az értékeket csökkenthetik az országkockázati plafonok, mivel egy fedezett kötvény minősítése sem haladhatja meg az országkockázati plafont. Ez a belföldi pénznemben kibocsátott kötvények esetében maximum 6 notch-csal meghaladhatja a belföldi pénznemben kibocsátott államkötvények szuverén besorolását. A devizában kibocsátott fedezett kötvények esetén az országkockázati plafon jellemzően o-3 notch-csal alacsonyabb, mint a hazai pénznemben meghatározott országkockázati plafon.

\subsubsection{Fitch $^{16}$}

A fedezett kötvények minősítésének kiindulópontja a Fitch esetében is a kibocsátó bank minősítése, amelyet 1 vagy 2 notch-val növelhet meg a hitelezői feltőkésítés alól való kivonás lehetősége. Akárcsak a Moody’s esetében, ezt követően itt is a fizetések további fenntarthatóságának a fedezett kötvény minősítésére gyakorolt hatását elemzik, abban az esetben, ha a kibocsátó beszünteti a kötvényekben

$16 \mathrm{Az}$ ismertetés alapja: Fitch Ratings (2020a; 2020b). 
megtestesülő követelések kifizetését. Ezt a Fitch PCU-nak (Payment Continuity Uplift) hívja. A Fitch a PCU keretében adható többlet notch-ok kalibrálásánál azt vizsgálja, hogy mennyire hatásos a fedezett kötvény konstrukciójában meglévő likviditási védelem. A likviditási védelem lehet akár jogszabályi előíráson alapuló, akár pedig szerződéssel biztosított. A legmagasabb, 8 notch emelés akkor adható, ha a likviditási védelem időtartama meghaladja a fedezettkötvény-portfólió legtávolabbi időben lejáró elemének a lejáratát. Ennél kevesebb, 6, 5, 4 vagy 3 notch emelés adható attól függően, hogy a likviditási támogatás hány hónapra terjed ki, hogy a fedezetül szolgáló portfólió jelzáloghitelekből, közszférának nyújtott hitelekből vagy ezek együtteséből áll, illetve hogy a fejlett vagy a fejlődő bankpiacokon nyújtott hitel adja-e a fedezeteket. A PCU keretében adott minősítésjavítás ezeknél az értékeknél kisebb is lehet, ha vannak olyan kockázatok, amelyek a kifizetések folyamatosságát alááshatják. Ilyen kockázat lehet például, ha a fedezett eszközök nem megfelelően vannak elkülönítve a kibocsátó bank könyveiben.

A harmadik lehetőség arra, hogy a Fitch tovább emelje a bankminősítéshez képest a fedezett kötvény minősítését, az, ha amikor a kibocsátó beszünteti a kötvények kifizetését, akkor a kötvényeket alkotó hitelcsomag mögöttes fedezetéből is számottevő (a kötvény névértékének felét meghaladó) megtérülést várhatnak a kötvénytulajdonosok. Ilyen esetekben a várható megtérülés besorolása lehet jó, nagyon jó vagy kiváló, és ennek függvényében 1-3 notch-csal javítható a minősítés.

A Fitch minősítési folyamatában a minősítést javító tényezők számbavételét követően kerül sor arra, hogy elemezzék, mekkora túlfedezettségre van szükség ahhoz, hogy a hitelportfólióból származó cash flow még egy stresszforgatókönyv esetén is fedezze a kötvénytulajdonosok felé vállalt fizetési kötelezettségeket, valamint ahhoz, hogy a fedezeti portfólióból való megtérülés miatti 1-3 notch-csal való minősítésjavítás még egy stresszforgatókönyv esetén is reális legyen. A Fitch minden egyes minősítési kategóriához meghatározza, hogy a kibocsátó minősítéséből kiindulva mekkora túlfedezettséget vár el ahhoz, hogy a minősítésjavító notchokat valóban alkalmazni lehessen. Ha a túlfedezettség ezt az adott mértéket nem éri el, akkor az egyébként a módszertan alapján járó összes notch-emeléseket 1 notch-csal csökkentheti a Fitch.

Összességében tehát a Fitch módszertana szerint a maximális javítási lehetőség 13 notch, vagyis elvileg a $\mathrm{B}+$ minősítésü, erősen spekulatív kategóriába tartozó kibocsátó fedezett kötvénye is lehet AAA minősítésű, ha a vonatkozó feltételek teljesülnek.

Az országkockázat mint a minősítés javításának felső határa a Fitch esetében is része a módszertannak. Így a maximum 13 notch-nyi minősítésjavítás csak az országkockázati plafonon belül használható ki. Az országkockázati plafon hazai pénznemben denominált fedezett kötvények esetén a hazai pénznemben való szuverén kötvénykibocsátások minősítése plusz maximum 6 notch lehet. A devizában 
denominált fedezett kötvények esetében általában nem haladhatja meg a kötvények minősítése az államkötvényekét, hacsak a kötvényekhez kapcsolódó konvertibilitási és átutalási kockázatok nincsenek kimutathatóan csökkentve. Ez utóbbi esetben a devizában denominált fedezett kötvények minősítése maximum 4 notch-csal lehet nagyobb, mint a szintén devizában denominált, szuverén kötvényeké.

\subsubsection{Standard and Poor $(S \& P)^{17}$}

A fedezett kötvények minősítésénél az S\&P is a kötvényt kibocsátó bank minősítéséből indul ki. Ezt követően itt is azoknak a tényezőknek a meghatározása következik, amelyek javíthatják a fedezett kötvény minősítését a kibocsátó minősítéséhez képest. Az első javító tényező az S\&P esetében is az, hogy a fedezett kötvények nem vonhatók be a hitelezői feltőkésítésbe. Ez 1 vagy 2 notch-nyi felminősítést eredményezhet. Ezt követően állapítják meg a maximálisan elérhető fedezettkötvény-minősítést, ami itt is azon tényezők számbavételét jelenti, amelyek mentén a minősítés javítható. Ezek a tényezők két csoportba sorolhatók. Az első csoportba tartoznak a jogszabályokból következő támogatások, amelyek lehetnek gyengék, mérsékeltek, erősek vagy nagyon erősek, és ennek függvényében 1, 2 vagy 3 notch többlet adható a minősítéshez. A második csoportba azok a fedezeten alapuló piaci lehetőségek tartoznak, amelyek szintén azt segíthetik elö, hogy ha a kibocsátó beszünteti a kötvény kifizetéseit, a kötvénytulajdonosok továbbra is változatlanul megkapják a nekik járó pénzösszegeket. Ennek keretében a kötvény mögötti fedezetet adó hitelportfólió minőségét (hitelkockázatát), valamint a portfólió refinanszírozásának kockázatait elemzik. Ez utóbbival kapcsolatban annál nagyobb a minősítés javításának a lehetősége, minél likvidebb az a másodlagos piac, ahol a kötvények refinanszírozására forrásokat lehet gyüjteni. A két tényező együttesen maximum 4 notch-csal növelheti a jogszabályokon alapuló támogatások után kialakuló minősítés szintjét. Ha a kötvények mögött nem áll olyan likviditási támogatási rendszer, amelyik legalább hat hónapra képes biztosítani a kötvénykifizetéseket akkor is, ha a kibocsátó beszüntette a kifizetéseket, illetve, ha a fedezett kötvény mögött nincs meg az elvárt túlfedezettség, akkor a minősítést 1-1 notch-csal csökkenti az S\&P.

Az így kapott minősítés maximálisan 9 notch-csal lehet magasabb a kibocsátó bank minősítésénél, ami azt jelenti, hogy a legrosszabb minősítésű kibocsátó, amelyiknek a fedezett kötvénye még elérheti az AAA minősítést, az a befektetési kategória legalsó értékét jelentő BBB- kategóriába tartozik. Spekulatív (BB+ vagy az alatti) kibocsátói minősítésről nem lehet AAA-ra javítani a fedezett kötvény minősítését.

17 Az ismertetés alapja: S\&P Global Ratings (2015) és S\&P Global Ratings (2019). 
Az országkockázati plafont az S\&P esetében nem a hazai pénznemben vagy a devizában való kibocsátás szerint különítik el, hanem aszerint, hogy a kibocsátó és a fedezett kötvényeket megtestesítő fedezetek halmaza ugyanabban az országban van-e. Ez esetben az országkockázati plafon legfeljebb 6 notch-csal lehet magasabb a szuverén kötvények minősítésénél. Ha a kibocsátó és a fedezetek halmaza különböző országokban van, akkor az S\&P a B (erősen spekulatív besorolás) vagy jobb minősítésü országok esetében maximum 6 notch-csal javíthatja a fedezett kötvények minősítését, míg az ennél rosszabb minősítésű országok esetében maximum BB-re.

\subsubsection{DBRS $^{18}$}

A DBRS minősítési rendszere négy lépésből áll. Az első lépésben határozzák meg a minősítésének kiindulópontját. Ez a kibocsátó bank minősítésénél legfeljebb 2 notch-csal lehet magasabb, itt is a szanálási folyamatban való kedvezményes kezelés miatt. A második lépés a jogi és strukturális tényezők függvényében határozza meg azt, hogy hány notch-csal javítható a minősítés az első lépés eredményéhez képest. A felfelé való eltérések mértéke annál nagyobb, minél inkább valószínü, hogy a kibocsátó bank bukása esetén is az eredeti feltételekkel folytatódhatnak a fedezett kötvényhez kapcsolódó kifizetések. Ez elsősorban jogi megközelítésü elemzést jelent, aminek a megítélése során a DBRS három tényezőt vesz figyelembe:

1) mennyire megvalósítható a fedezett kötvényportfólió tényleges elkülönítése a kötvénytulajdonosok érdekében;

2) a fedezett kötvényportfólióból származó cash flow megfelelő időben való hozzáférhetősége úgy a jogi környezet, mint a strukturális tényezők alapján;

3) a kibocsátó bank bukása esetén van-e a fedezett kötvények folyamatos fizetésére vonatkozó üzletfolytonossági terv, és ehhez kapcsolódó felügyeleti támogatás.

Ennek a lépésnek az eredményeként a fedezett kötvénykibocsátásokat öt kategóriába sorolják.

A jogi és strukturális keretrendszer lehet gyenge, átlagos, megfelelő, erős vagy nagyon erős. A nagyon erős besorolás esetében a maximális minősítésjavítási lehetőség 6 notch. A harmadik lépésben készül el a kötvények mögötti fedezetek halmazának minősítése, amelynek a módszertana a nemteljesítési valószínűség és a nemteljesítés esetén bekövetkező veszteség mértékének becslésén alapul. Ezt az eszközök cash flow-jának stresszforgatókönyv mentén való becslése is kiegé-

$18 \mathrm{Az}$ ismertetés alapja: DBRS (2020). 
szíti. Itt veszik figyelembe a portfólió túlfedezettségét is. Ezt a lépést követően készülnek el a DBRS fedezettkötvény-minősítésének mátrixai. A második lépésben meghatározott jogi és strukturális besorolásnak mind az öt kategóriájához egy-egy mátrix készül, amelynek két dimenzióját az első lépésben meghatározott kiinduló minősítések és a harmadik lépésben meghatározott fedezetihalmazminősítések adják. A nagyon erős jogi és strukturális keretrendszerhez tartozó mátrix esetében, ha a kiinduló minősítés A (low), vagyis 6 notch-csal marad el a AAA-tól, és a kibocsátó bank minősítése ettől akár további 2 notch-csal elmaradó, vagyis BBB is lehet, még akkor is kaphat a fedezett kötvény AAA minősítést, ha a fedezeti halmaz minősítése AAA. A leggyengébb jogi és strukturális keretrendszerhez tartozó mátrix esetében már csak az AAA és AA (high) kiinduló minősítésekhez [legalább AA (low) besorolású kibocsátó] tartozhatnak AAA minősítésü fedezett kötvények. A negyedik lépésben, amennyiben a DBRS úgy találja, hogy a fedezettkötvény-portfólió számottevő támogatást jelenthet a fedezett kötvény nemteljesítése esetén, további 2 notch-csal javíthatja a harmadik lépésben felállított mátrixokban szereplő minősítéseket.

A DBRS módszertanába a jelzáloggal fedezett kötvények esetében nincs beépítve konkrét országkockázati besoroláshoz kötött plafon, de számos lépésnél figyelembe veszik az országkockázat esetleges növekedésének hatását is. Ha a fedezetek a kötvények mögött a közszférának nyújtott hitelek állnak, akkor viszont a minősítésük legfeljebb 3 notch-csal haladhatja meg a kibocsátó bank székhelye szerinti ország szuverén minősítését.

\subsubsection{Scope ${ }^{19}$}

A fedezett kötvények minősítésének kiindulópontja a Scope esetében is a kibocsátó bank minősítése, ezt azonban nem növelik meg indulásként a hitelezői feltőkésítésbe való bevonhatóság hiánya miatt, hanem azt a jogi keretrendszer részeként értékelik. A módosítások közül a Scope esetében az első lépést azoknak az alapvető támogatási rendszereknek az értékelése jelenti, amelyek miatt a fedezett kötvények a kibocsátó bank esetleges válsága esetén is folyamatosan képesek teljesíteni a kifizetéseket. Ebben a lépésben két tényezőt elemez a Scope: a banki szanálási szabályokat és a fedezett kötvényekre vonatkozó jogi keretrendszert. Itt a szanálási szabályok értékelésébe tartozik a hitelezői feltőkésítés alóli kivonás lehetőségének értékelése is, de emellett itt értékelik mindazokat a szempontokat, amelyek azt támogatják, hogy egy bankcsőd esetén a szabályozók preferenciálisan kezeljék az adott fedezett kötvényt. Ilyen lehet pl. a fedezett kötvények piacának rendszerszíntű fontossága az adott országban. Összességében a szanálási rendszer

$19 \mathrm{Az}$ ismertetés alapja: Scope (2020). 
fedezett kötvényeket támogató jellege miatt 4 notch többlet adható. A jogi keretrendszer nem a szanálás szakaszában meglévő kifizetéstámogató eszközöket veszi számba, hanem azokat, amelyek nem a megállapított inszolvencia szakaszában működnek, hanem azt megelőzően vagy azt követően. Ennek keretében további 2 notch-csal növelhető a minősítés. Vagyis a szanálási és jogi keretnek a kifizetéseket támogató jellege összességben a kibocsátó bank minősítéséhez képest maximum 6 notch-csal jobb minősítést eredményezhet.

A következő lépésben értékelik a fedezettek halmazának a minőségét. Ennek elemzése során három tényezőt vizsgál a Scope. Ezek:

1) a fedezetként szereplő eszközök és a belölük származó cash flow-k értékelése várhatóveszteség-alapú modell használatával;

2) a kibocsátó kockázatkezelésének minősége;

3) a túlfedezettség mértéke.

Ebben a lépésben további 3 notch-csal javítható a minősítés. A Scope esetén nincs arra vonatkozó plafon, hogy a fedezett kötvény minősítése legfeljebb mennyivel haladhatja meg az országkockázatot.

További sajátossága a Scope módszertanának, hogy a második lépésben megvalósuló fedezetihalmaz-elemzést csak akkor tekinti a minősítést meghatározó tényezőnek, ha az első lépés (szanálási és jogi keretrendszer) elemzése során adott többlet notch-okkal a fedezett kötvény minősítése még nem érte el a AAA szintet. Amennyiben elérte, akkor a fedezeti halmaz minősége már nem játszik szerepet a minősítésben, csak a minősítés stabilitásának valószínűsége szempontjából fontos tényezőként tekintenek rá. Ez esetben a fedezetek halmazának elemzése nem teljes körüen történik meg.

\section{AZ ÖT HITELMINÖSÍTŐ MÓDSZERTANÁNAK ÖSSZEHASONLÍTÁSA}

Mind az öt hitelminősítő esetében elmondható, hogy a fedezett kötvények minősítése jellemzően számos kategóriával meghaladhatja úgy a kötvényeket kibocsátó bank, mint a bank székhelyéül szolgáló ország szuverén minősítését. A kibocsátó bank minősítése felett adható lehetséges többlet notch-ok összetételét és mértékét a 3. táblázat tartalmazza. A táblázatban feketével jelöltük azokat a cellákat, amelyek a kiinduló minősítés meghatározását követően az első logikai lépést jelentik az adott minősítő rendszerén belül.

A hitelminősítők közül a Fitch-nél van a legtöbb lehetőség a kibocsátó minősítésénél jobb minősítés megállapítására, 13 notch-csal, de a többi minősítőnél is 9 vagy 10 notch javításra van lehetőség. A spekulatív minősítési kategória teteje 
mindegyik hitelminősítőnél 10 notch-ra van a AAA minősítéstől, így elmondható, hogy nem túl jó minősítésü bankok által kibocsátott kötvények is elég könnyen kerülhetnek a AAA-s vagy a AA-s, gyakorlatilag kockázatmentes kategóriába. Ezt igazolja az is, hogy az EKB fedezettkötvény-vásárlásaihoz készített benchmark számításai szerint 2018 végén az euróövezetben kibocsátott fedezett kötvények 76,5\%-a AAA minősítésü, 20,4\%-a AA minősítésü, 2,7\%-a A minősítésü volt, és mindössze $0,3 \%$ tartozott a BBB kategóriába (ECB, 2019:79).

A 3. táblázat 6. és 7. sora azt mutatja meg, hogy a fedezett kötvényekre vonatkozó országkockázati plafon az adott hitelminősítőnél hogyan viszonyul a bank székhely szerinti országának szuverén kötvényekre vonatkozó minősítéséhez, vagyis az országkockázati plafon mennyiben korlátozhatja azt, hogy az adott fedezett kötvény megkaphassa a minősítés szerint kialakuló, összes többlet notch-ot. Láthatjuk, hogy nem igazán.

\section{3. táblázat}

A kibocsátó bank minősítése felett adható maximális javítási lehetőségek (notch-ok)

\begin{tabular}{|c|c|c|c|c|c|c|}
\hline & & Moody's & Fitch & $\mathrm{S} \& \mathrm{P}$ & DRBS & Scope \\
\hline 1 & $\begin{array}{l}\text { Kiinduló minősítés a } \\
\text { hitelezői feltőkésítésbe } \\
\text { való bevonás } \\
\text { lehetőségének hiánya } \\
\text { miatt }\end{array}$ & 1 & 2 & 2 & 2 & $\begin{array}{l}0 \text { (a jogi keret- } \\
\text { rendszernél } \\
\text { veszik figye- } \\
\text { lembe) }\end{array}$ \\
\hline 2 & $\begin{array}{l}\text { Jogi és strukturális } \\
\text { keretrendszer }\end{array}$ & 4 & & 3 & 6 & 6 \\
\hline 3 & $\begin{array}{l}\text { Fedezeti halmaz } \\
\text { értékelése }\end{array}$ & 5 & 3 & 4 & 2 & 3 \\
\hline 4 & Likviditási védelem & & 8 & & & \\
\hline 5 & $\begin{array}{l}\text { ÖSSZESEN - maximális } \\
\text { eltérítési lehetőség }\end{array}$ & 10 & 13 & 9 & 10 & 9 \\
\hline 6 & $\begin{array}{l}\text { Országkockázati plafon } \\
\text { a szuverén besorolás } \\
\text { felett (hazai pénznemben } \\
\text { denominált kötvények) }\end{array}$ & 6 & 6 & 6 & $\begin{array}{l}\text { jelzálog-fedezetnél } \\
\text { nincs meghatározva; } \\
\text { ha a fedezet } \\
\text { közszférának nyújtott } \\
\text { hitel: } 3\end{array}$ & nincs \\
\hline 7 & $\begin{array}{l}\text { Országkockázati plafon a } \\
\text { szuverén besorolás felett } \\
\text { (devizában denominált } \\
\text { kötvények) }\end{array}$ & 6 & 4 & 6 & $\begin{array}{l}\text { jelzálog-fedezetnél } \\
\text { nincs meghatározva; } \\
\text { ha a fedezet } \\
\text { közszférának nyújtott } \\
\text { hitel: } 3\end{array}$ & nincs \\
\hline
\end{tabular}

Forrás: saját összeállítás 
Ahogy az a 3. táblázatban látható, a fedezett kötvények minősítésének módszertanában a jogi és szabályozási környezet (beleértve a bankszanálási szabályokat is) összességében mindegyik minősítő esetében nagyobb szerepet játszik, mint magának a fedezeti halmaznak a minősége. A minősítéseknél a kiindulópont is alapvetően a fedezett kötvények jogi védelme az S\&P, a DRBS és a Scope esetében. A Fitch által elsődlegesen elemzett likviditási védelem is inkább a jogszabályokkal, szerződésekkel körülbástyázott védelemre fókuszál, kevésbé a kockázatkezelésből, portfólióminőségből fakadó tényezőkre. A Moody’s módszertana követ egyedül fordított logikát, ott a fedezeti halmaz minőségének elemzése megelőzi a jogi és strukturális keretrendszer értékelését. A portfólió minőségi elemzésének másodlagossága a leghangsúlyosabb a Scope esetében, ahol ha a jogi környezet okán már AAA-ra javult a minősítés, akkor a fedezeti halmaz elemzését nem is végzik el teljes körűen, vagyis nem lehet pontosan tudni, mekkora puffer (kihasználatlan többlet notch) van a minősítésben.

\section{KÖVETKEZTETÉSEK}

A cikk a hitelminősítőknek a fedezett kötvények minősítésére vonatkozó gyakorlatát mutatta be, elemezte és hasonlította össze. Rámutatott, hogy a fedezett kötvények a hitelminősítők alkalmazott módszertanából adódóan a kimagaslóan jó minősítésű kötvények közé tartoznak, minősítésük számottevően meghaladhatja úgy a kibocsátó bank, mint a bank székhelyéül szolgáló ország minősítését. A fedezett kötvények - jogi konstrukciójuknak köszönhetően - valóban jóval kisebb kockázatot hordoznak, mint az azt kibocsátó bank fedezetlen kötvényei, hiszen a bank csődje esetén is több védelmi vonal áll rendelkezésre a kötvénytulajdonosok kockázatainak csökkentésére. Az is tény, hogy a 2008-as globális pénzügyi válság és az azt követő euróövezeti válság alatt, miközben a CDO-k tömegesen értéktelenedtek el, a fedezett kötvények piacán nem voltak összeomlások. Igaz, számos bajba került kibocsátó bank részesült állami mentőcsomagban, aminek a hatására a banki források tulajdonosainak (nemcsak a fedezettkötvény-tulajdonosoknak) sokszor nem keletkezett vesztesége. Ugyanakkor az, hogy az euróövezeten belül a fedezett kötvények több mint 99\%-a legalább A minősítésű, illetve, hogy több mint háromnegyedük AAA minősítésű, azt az illúziót kelti, hogy a fedezett kötvények gyakorlatilag kockázatmentes eszközök, a nem AAA minősítésű országok esetében sokkal kevésbé kockázatosak, mint az állampapírok. A minősítők bemutatott módszertana még azt is sejteti: ha lenne kifejezésünk arra, hogy „még a legeslegjobbnál is jobb”, akkor a fedezett kötvények közül sok akár oda is tartozhatna, hiszen sokszor a maximálisan adható többlet notch-oknál kevesebbre van csak szükség a AAA kategória eléréséhez. 
Ugyanakkor a fedezett kötvények nyilvánvalóan nem kockázatmentes termékek. Érzékenyek az ingatlanárak csökkenésére, az ingatlanpiaci összeomlásokra. A 2008-as globális válságot követően Európa több országában is volt jelentős ingatlanpiaci visszaesés, voltak bankcsődök is, de a fentebb említett állami mentőcsomagok okán nem derülhetett ki, hogy a fedezett kötvények vajon az adott szuverén és/vagy bankválság körülményei közepette is folyamatosan képesek lettek volna-e teljesíteni a kifizetéseket a kötvénytulajdonosok felé. Így az sem volt még soha kipróbálva, hogy a banki és szuverén minősítéstöl valóban ekkora mértékben elszakítható-e a fedezett kötvények minősítése, hiszen egy esetleges szuverén csőd bekövetkezésekor a szabályozásban, jogi garanciákban megmutatkozó védelem ereje is számottevően megkérdőjeleződhet.

A 2008-as válságot követően az is nehezíti a fedezett kötvények minősítésének megítélését, hogy a kiváló minősítésre való tekintettel a jegybankok (az euróövezetben az EKB) lettek a fedezett kötvények fő vásárlói, ami automatikus, de nem hosszú távra garantált piacvédelmet ad ennek a piaci szegmensnek. Az EKB által fenntartott kedvező piaci helyzet is hozzájárul ahhoz, hogy a fedezett kötvények rendkívül jó befektetési eszköznek számítsanak. Ez, ha formálisan nem is része a minősítési módszertannak, implicit módon hozzájárul a kiváló minősitések fenntarthatóságához.

Összességében a cikk fő következtetése, hogy a hitelminősítöknek a fedezett kötvények minősitésére alkalmazott módszertana nagyon könnyen eredményez kimagaslóan jó minősítést, amit sem a kibocsátó bank, sem pedig a bank székhelye szerinti ország minősítése nem korlátoz igazán. A minősítések kialakítása során elsődleges szerepe van a szabályozási környezetből származó extra védelemnek, ami általában jól működik, de kérdéses, hogy egy igazán jelentős piaci összeomlás esetén is müködőképes lenne-e. 


\section{MELLÉKLET}

Az elemzésbe bevont öt hitelminősítő minősítési skálájának összehasonlítása

\begin{tabular}{|c|c|c|c|c|c|}
\hline & Moody's & S\&P & Fitch & DBRS & Scope \\
\hline \multirow{10}{*}{$\begin{array}{l}\text { Befektetési } \\
\text { kategória }\end{array}$} & Aaa & AAA & AAA & AAA & AAA \\
\hline & Aal & $\mathrm{AA}+$ & $\mathrm{AA}+$ & AA (high) & $\mathrm{AA}+$ \\
\hline & $\mathrm{Aa} 2$ & AA & AA & AA & $\mathrm{AA}$ \\
\hline & Aa3 & AA- & AA- & AA (low) & AA- \\
\hline & A1 & $\mathrm{A}+$ & $\mathrm{A}+$ & A (high) & $\mathrm{A}+$ \\
\hline & $\mathrm{A} 2$ & A & A & A & A \\
\hline & $\mathrm{A} 3$ & A- & A- & A (low) & A- \\
\hline & Baal & $\mathrm{BBB}+$ & $\mathrm{BBB}+$ & BBB (high) & $\mathrm{BBB}+$ \\
\hline & $\mathrm{Baa} 2$ & $\mathrm{BBB}$ & $\mathrm{BBB}$ & $\mathrm{BBB}$ & $\mathrm{BBB}$ \\
\hline & Baa3 & $\mathrm{BBB}-$ & BBB- & BBB (low) & BBB- \\
\hline \multirow{11}{*}{$\begin{array}{l}\text { Spekulatív } \\
\text { kategória } \\
\text { (bóvli) }\end{array}$} & Bal & $\mathrm{BB}+$ & $\mathrm{BB}+$ & BB (high) & $\mathrm{BB}+$ \\
\hline & $\mathrm{Ba} 2$ & $\mathrm{BB}$ & $\mathrm{BB}$ & $\mathrm{BB}$ & $\mathrm{BB}$ \\
\hline & $\mathrm{Ba} 3$ & $\mathrm{BB}-$ & BB- & BB (low) & BB- \\
\hline & B1 & $\mathrm{B}+$ & $\mathrm{B}+$ & B (high) & $\mathrm{B}+$ \\
\hline & B2 & B & B & B & B \\
\hline & B3 & $\mathrm{B}-$ & $\mathrm{B}-$ & B (low) & $\mathrm{B}-$ \\
\hline & Caal & $\mathrm{CCC}+$ & CCC & CCC (high) & CCC \\
\hline & $\mathrm{Caa} 2$ & CCC & & CCC & CC \\
\hline & Caa3 & CCC- & & CCC (low) & $\mathrm{C}$ \\
\hline & \multirow{2}{*}{$\mathrm{Ca}$} & $\mathrm{CC}$ & $\mathrm{CC}$ & CC (high) & \\
\hline & & $\mathrm{C}$ & $\mathrm{C}$ & $\mathrm{CC}$ & \\
\hline Fizetésképtelen & $\mathrm{C}$ & $\mathrm{D}$ & $\mathrm{D}$ & $\mathrm{C}$ & $\mathrm{D}$ \\
\hline
\end{tabular}




\section{HIVATKOZÁSOK}

DBRS (2020): Methodology - Rating and Monotoring Covered Bonds. April, https://www.dbrsmorningstar.com/research $/ 360260 /$ rating-and-monitoring-covered-bonds.

EBA (2014): EBA report on covered bond frameworks and capital treatment. https://www.eba. europa.eu/sites/default/documents/files/documents/1018o/534414/fa5bf6ec-6301-4b9o-8f983324333 c82a4/EBA\%2oReport\%20on\%2oEU\%2oCovered\%2oBond\%2oFrameworks\%2oand\%2O Capital\%2oTreatment.pdf?retry=1.

EBA (2016): EBA Report on Covered Bonds. EBA-OP-2016-23. https:/www.eba.europa.eu/sites/ default/documents/files/documents/1018o/1699643/d2bo8b75-6o1f-4de3-ba36-ad674cdcod46/ EBA\%20Report\%20on\%2oCovered\%20Bonds\%20\%28EBA-Op-2016-23\%29.pdf?retry=1.

EC (2015): Action Plan Building a Capital Markets Union. COM(2015)468 final. https://ec.europa.eu/ transparency/regdoc/rep/1/2015/EN/1-2015-468-EN-F1-1.PDF.

ECB (2019): Economic Bulletin, Issue 2. https://www.ecb.europa.eu/pub/pdf/ecbu/ eb201902 a07oc3a338.en.pdf.

ECBC (2020): European Covered Bond Fact Book 2020. https://hypo.org/ecbc/publications/factbook/.

ESMA (2020): Report on CRA Maket Share Calculation. ESMA 33-9-32, 14 December, https:// www.esma.europa.eu/sites/default/files/library/esma_33-9-383_cra_market_share_calculation_2020_o.pdf.

Fitch Ratings (2020a): Covered Bonds Rating Criteria. 18 November, https://www.fitchratings.com/ research/structured-finance/covered-bonds/covered-bonds-rating-criteria-18-11-2020.

Fitch Rating (2020b): Structured Finance and Covered Bonds Country Risk Rating Criteria. 23. September, https://www.fitchratings.com/research/structured-finance/structured-finance-covered-bonds-country-risk-rating-criteria-23-09-2020.

Gaillard, N. (2013): What is the Value of Sovereign Ratings? German Economic Review, 15(1), 208224.

Kemmish, R. - Wilkinson, C. - Andruszkiewicz, O. (2017): Covered Bonds in the European Union: Harmonisation of legal frameworks and market behaviours. Final report, European Commission.

Moody's Investor Service (2020a): Rating transition rates for covered bond deals, 1997-2019. https:// www.moodys.com/researchdocumentcontentpage.aspx?docid=PBS_1117861.

Moody's Investor Service (2020b): Rating methodology - Moodys's Approach to Rating Covered Bonds. October 26, https://www.moodys.com/research/Moodys-updates-its-methodology-forrating-covered-bonds--PBS_1248889.

Moody's Investor Service (2020c): Country Ceilings Methodology. December 7, https://www.moodys.com/researchdocumentcontentpage.aspx?docid=PBC_1225594.

Mullard, M. (2012) The Credit Rating Agencies and Their Contribution to the Financial Crisis. The Political Quarterly, 83(1), 77-95.

S\&P Global Ratings (2015): Covered Bonds: Covered Bond Rating Frameworks: Methodology and Assumptions. https://www.standardandpoors.com/en_US/web/guest/ratings/ratings-criteria/-/articles/criteria/structured-finance/filter/covered-bonds.

S\&P Global Ratings (2019): Incorporating Sovereign Risk in Rating Structured Finance Securities: Methodology and Assumptions. https://www.standardandpoors.com/en_US/web/guest/ratings/ratings-criteria/-/articles/criteria/structured-finance/filter/general.

Scalet, S. - Kelly, T. F. (2012) The Etics of Credit Rating Agencies: What Happened and the way Forward. Journal of Business Ethics, 111, 477-490. 
STÖCKER, O. (2020) Overview of covered bonds. In ECBC (2020), 143-150.

STöcker, O. (2021) A fedezett kötvények európai uniós jogharmonizációja. Gazdaság és Pénzügy, $8(1), 26-59$.

White, L. J. (2009) The credit rating agencies and the subprime debacle. Critical Review 21(2-3), 389-399. 